\title{
Partikel Majemuk To Doujini Dan To Tomoni Dalam Kalimat Bahasa Jepang
}

\author{
E.I.H.A Nindia Rini*, Lindha Arfiana \\ Universitas Diponegoro \\ *E-mail: eliz_ikahesti@yahoo.co.id
}

\begin{abstract}
Abstrak
To doujini dan to tomoni termasuk ke dalam partikel majemuk (fukugoukakujoshi) dalam bahasa Jepang yang sama-sama berfungsi menyatakan dua hal yang terjadi atau berlangsung secara bersamaan. Tujuan penelitian ini untuk mendeskripsikan struktur dan makna partikel majemuk to doujini dan to tomoni. Metode yang digunakan adalah metode agih dengan teknik bagi unsur langsung. Berdasarkan penelitian diketahui bahwa secara struktur to doujini dan to tomoni dapat berkonstruksi dengan verba, adjektiva, dan nomina. Secara makna to doujini memiliki tiga makna, yaitu 'pada saat yang sama', 'segera setelah', serta 'dan juga'; to tomoni juga memiliki tiga makna, yaitu 'pada saat yang sama', 'seiring dengan', dan 'bersama dengan'.
\end{abstract}

Kata kunci : fukugoukakujoshi; to doujiini; to tomoni

\begin{abstract}
(Title: Fukugoukakujoshi To Doujini and To Tomoni in Japanese Language) To doujini and to tomoni in Japanese are fukugoukakujoshi (compound particles) which are both used to express two things that occur or take place simultaneously. The purpose of this study is to describe the structure and meaning of fukugoukakujoshi to doujini and to tomoni in Japanese sentences. The method used in this research is Agih with Bagi Unsur Langsung techniques. Based on research it is known that structurally to doujini and to tomoni can be attached to verbs, adjectives, and nouns. In terms of to doujini it has three meanings, that was 'at the same time', 'immediately after', and 'and also'; to tomoni also has three meanings, that was 'at the same time', 'along with', and 'together with'.
\end{abstract}

Keywords : fukugoukakujoshi; to doujiini; to tomoni

\section{PENDAHULUAN}

Partikel majemuk atau fukugoukakujoshi adalah gabungan dari dua kata atau lebih yang membentuk sebuah partikel, di mana partikel tersebut ditafsirkan sebagai satu partikel daripada kata demi kata (Machida, 2001:648). To doujini, to tomoni merupakan salah satu contoh fukugoukakujoshi.

Penelitian terdahulu yang terkait dengan penelitian ini adalah penelitian dari Fitriyani (2012) yang berjudul "Analisis
Penggunaan Pola Kalimat ToTomoni, Ni Shitagatte, Ni Tomonatte, dan Ni Tsurete dalam Kalimat Bahasa Jepang”. Berdasarkan penelitian yang dilakukan oleh Fitriyani dapat disimpulkan bahwa bahwa keempat bentuk tersebut sama-sama bermakna 'seiring', dapat melekat pada verba, dan pada kasus tertentu dapat saling menggantikan.

Perbedaan penelitian penulis dengan penelitian terdahulu adalah pembahasan struktur dan makna to tomoniyang belum 
dibahas secara mendetail pada peneltian sebelumnya, dan penambahan todoujini sebagai pembanding karena sama-sama memiliki makna 'pada saat yang sama'

Selain itu, terdapat penelitian Kholifah (2017) yang berjudul "Analisis Struktur dan Makna Adverbia Tomoni dalam Bahasa Jepang”. Sebagai hasil penelitian ini, disimpulkan bahwa dilihat dari segi struktur, to tomoni tidak selalu berdampingan dengan kata yang dimodifikasi, dengan struktur sebagai berikut : N1wa / ga N2to tomoni o V; $\mathrm{V}_{1}$ to tomoni $\mathrm{V}_{2} ; \mathrm{N}_{1}, \mathrm{~N}_{2} w a$ / ga tomoni $\mathrm{N}_{3}$; dan Tomoni $\sim \mathrm{Ni}, \mathrm{N}_{2} g a \mathrm{~V}$. Kemudian dilihat dari segi makna, to tomoni menyatakan makna 'bersama' (いしょに) untuk aktivitas yang dilakukan bersama dengan seseorang; 'bersamaan' (同時に) untuk dua aktivitas atau peristiwa yang terjadi pada satu waktu; atau untuk situasi sejalan dengan adanya perubahan tertentu terdapat perubahan lain yang mengikutinya; dan 'keduanya' (両方) untuk dua hal yang memiliki kesamaan.

Perbedaan penelitian penulis dengan penelitian Kholifah adalahteori yang digunakan dalam kajianto tomoni, pada penelitian Kholifah digunakan teori Saichiro yang memandang bahwa to tomoni merupakan adverbia, sedangkan penulis menggunakan teori Nitta dan Sunagawa yang menyatakan bahwato tomoni merupakan partikel majemuk. Selain itu penelitian ini juga menambahkan todoujiniuntuk pembanding karena samasama memiliki makna 'pada saat yang sama'.

Tujuan penelitian ini adalah untuk memaparkan struktur dan makna dari todoujini dan totomoni yang memiliki perpotongan makna 'pada saat yang sama' atau dua hal yang terjadi pada waktu yang sama.

\section{METODE}

Pengumpulan data pada penelitian ini menggunakan metode simak dengan teknik sadap. Oleh karena data yang digunakan berupa tulisan, maka dalam praktiknya penyimakan diwujudkan dengan menyadap untuk mendapatkan data.

Data yang dikumpulkan kemudian dianalisis menggunakan metode agih dengan teknik bagi unsur langsung yaitu, membagi satuan datanya menjadi beberapa bagian atau unsur. Metode agih adalah metode yang alat penentunya merupakan bagian dari bahasa itu sendiri (Sudaryanto, 1993:15). Sedangkan teknik bagi unsur langsung diterapkan dengan membagi unsur-unsur sesuai dengan fungsinya dalam kalimat.

\section{HASIL DAN PEMBAHASAN Partikel Majemuk(Fukugoukakujoshi)}

Partikel majemuk atau dalam bahasa Jepang disebut dengan fukugoukakujoshi merupakan salah satu jenis partikel yang berarti beberapa kata yang terikat bersama atau bergabung dan berfungsi sebagai satu partikel.'ni tsuite', 'ni motodzuite', 'noseide', 'to totomoni' 'to doujini' dan yang lainnya disebut sebagai partikel majemuk.Hal ini selaras dengan pendapat Machida (2001:648) menjelaskan bahwa yang dimaksud dengan partikel majemuk (fukugoukakujoshi) adalahgabungan dari dua kata atau lebih yang membentuk satu partikel, di mana partikel tersebut ditafsirkan sebagai satu partikel daripada kata demi kata.

\section{Struktur dan Makna To Doujini Menyatakan 'Pada Saat yang Sama'} Menurut Nitta (2011:182) to doujini adalah partikel yang digunakan untuk menyatakan tindakan simultan atau dua hal yang berlangsung atau terjadi secara bersamaan. Hal itu selaras dengan Sunagawa (2002:309) yang menyatakan to doujini digunakan untuk menyatakan dua hal yang terjadi secara bersamaan. Dalam bahasa Indonesia dapat dipadankan dengan 'pada saat yang sama'. Dilihat dari segi struktur to doujini dengan makna 'pada saat yang sama' melekat pada verba, adjektiva, dan nomina. Berikut adalah contoh kalimat to doujini yang menyatakatan 'pada saat yang sama': 
(1) 蒸し暑いと同時に肌寒く感じる。

Mushiatsui / todoujini

$$
\text { (ejje.weblio.jp) }
$$

Gerah / pada saat yang sama

\section{/ hada samuku / kanjiru. \\ / dingin / merasa.}

'Saya merasa dingin dan gerah pada saat yang sama'

Pada kalimat (1) todouijini melekat pada adjektiva imushiatsui yang berarti 'gerah'. Di dalam kalimat adjektiva $i$ yang dilekati oleh todouijini tidak mengalami konjugasi atau perubahan, melainkan tetap pada bentuk aslinya. Todouijini pada kalimat (1) diikuti oleh adjektiva $i$ lainnya yaitu hadasamui 'dingin' yang juga mengalami konjugasi menjadi hadasamuku. Todouijini dalam kalimat (1) berfungsi untuk menjelaskan tentang dua keadaan yang terjadi dalam satu waktu yang bersamaan. Pada kalimat (1) subjek menjelaskan bahwa dirinya merasa gerah dan dingin pada saat yang bersamaan, dimana ketika pembicara merasa gerah pada saat yang sama juga pembicara merasakan kedinginan.

\section{Menyatakan 'Segera Setelah'}

Selain digunakan untuk menyatakan tindakan simultan atau dua hal yang berlangsung atau terjadi secara bersamaan, todoujini juga digunakan untuk menunjukkan bahwa hal berikutnya terjadi segera setelah hal sebelumnya terjadi (Nitta, 2011:182), dalam bahasa Indonesia dapat dipadankan dengan kata 'segera setelah'. Sejalan dengan itu Sunagawa (2002:309) juga menyebutkan bahwa todoujini juga dapat digunakan untuk menjelaskan hal berikutnya terjadi segera setelah hal sebelumnya terjadi. Dilihat dari segi struktur to doujini dengan makna 'segera setelah' melekat pada verba, adjektiva, dan nomina. Berikut adalah contoh kalimat todoujini yang menyatakan 'Segera setelah':

（2）目覚めると同時に家の大掃除に取 りかかった。

Mezameru/to doujini (ejje.weblio.jp) $\underline{\text { Bangun tidur / segera setelah }}$

/ ie / no / daisouji

/ rumah / PAR / bersih-bersih

/ ni / torikakatta.

/ PAR / memulai.

'Segera setelah saya bangun tidur, saya mulai membersihkan rumah'

Pada kalimat (2) to doujini melekat pada verba mezameru yang berarti 'bangun tidur'. To doujini pada kalimat (2) digunakan untuk menjelaskan bahwa seseorang melakukan aktivitas selanjutnya segera setelah atau tidak lama setelah seseorang tersebut melakukan aktivitas sebelumnya. Pada kalimat (2) dijelaskan bahwa subjek melakukan aktivitas membersihkan rumahnya segera setelah subjek tersebut bangun tidur. Untuk hal ini antara membersihkan rumah dan bangun tidur tidak memerlukan jangka waktu yang lama.

\section{Menyatakan 'Dan Juga'}

Todoujini juga digunakan untuk menunjukkan bahwa seseorang melakukan dua peran dalam satu waktu, atau suatu hal mempunyai dua karakteristik pada saat yang bersamaan (Makino dan Tsutsui, 2001:471). Pada bahasa Indonesia dapat dipadankan dengan kata 'dan juga'. Secara struktur to doujini dengan makna 'dan juga' dapat melekat pada verba, adjektiva, dan nomina. Berikut adalah contoh kalimat todoujini yang menyatakan 'dan juga': 
Kiryoku, Volume 3 No 42019

e-ISSN: 2581-0960 p-ISSN: 2599-0497

Tersedia online di http://ejournal.undip.ac.id/index.php/kiryoku

(3)

$$
\begin{aligned}
& \text { 彼は科学者であると同時に音楽 } \\
& \text { 家でもある。 (ejje.weblio.jp) }
\end{aligned}
$$

Kare / wa/ kagakusha de aru

$\mathrm{Dia} / \mathrm{PAR} /$ ilmuwan

/to doujini/ ongakuka demo aru. / dan juga /musisi.

'Dia seorang ilmuandan juga sekaligus musisi'

Pada kalimat (3) to doujini melekat pada nomina kagakusha yang berarti 'ilmuwan' dan karena nomina dilekati oleh to doujini maka ditambahkan de aru sebelum to doujini.To doujini pada kalimat (3) berfungsi untuk menunjukkan bahwa seseorang mempunyai atau melakukan dua peran sekaligus dalam kehidupannya,dalam kalimat (3) peran yang dimaksud adalah profesinya. Pada kalimat (3) dijelaskan bahwa subjek melakukan dua profesi sekaligus yaitu selain berprofesi sebagai ilmuwan subjek tersebut juga berprofesi sebagai musisi.

\section{Struktur dan Makna To Tomoni Menyatakan 'Pada Saat yang Sama'}

Nitta (2011:183) menjelaskan yang dimaksud dengan totomoni adalah ungkapan yang digunakan untuk mewakili tindakan simultan atau dua hal yang berlangsung atau terjadi secara bersamaan. Sejalan dengan Nitta, Sunagawa (2002:348) juga menyebutkan bahwa totomoni dapat di gunakan untuk menyatakan dua hal yang terjadi secara bersamaan, dalam bahasa Indonesia dapat dipadankan ke dalam kata 'pada saat yang sama'. Dilihat dari segi tsruktur totomoniyang bermakna 'pada saat yang sama' dapat melekat pada verba, adjektiva, dan nomina. Berikut adalah contoh kalimat totomoni yang meyatakan 'pada saat yang sama':

$$
\begin{aligned}
& \text { これを聞いた人々は平家の悪行 } \\
& \text { を怒ると共に重盛を褒め称えた。 }
\end{aligned}
$$

\author{
Kore / wo / kiita \\ Ini / PAR / mendengar
}

(ejje.weblio.jp)

/ hitobito / wa
/ orang-orang / PAR

/ Heike/no

/keluargaTaira(Heike)/ PAR

$\frac{\text { /akugyou }}{\text { /perbuatanjahat / }}$ / $\underline{\text { PAR }}$ / /

/totomoni

/ padasaatyangsama

/ Shigemori /wo / hometataeta.

/ Shigemori / PAR / memuji.

'Orang-orang yang mendengar berita ini, menjadi

marahatasperbuatanjahat

keluargaTaira(Heike), dan padasaatyangsama juga memuji Shigemori'

Pada kalimat (4) totomoni melekat pada verba okoru yang berarti 'marah'. Totomoni pada kalimat (4) berfungsi untuk menjelaskan bahwa dua aktivitas dilakukan pada saat yang sama. Pada kalimat (4) dijelaskan bahwa orang-orang yang mendengar berita mengenai perbuatan jahat keluarga Taira menjadi marah terhadap keluarga tersebut, akan tetapi pada saat yang bersamaan, orang-orang tersebut juga memberikan pujian kepada Shigemori.

\section{Menyatakan 'Seiring Dengan'}

To tomoni dengan makna 'seiring dengan' digunakan untuk menunjukkan bahwa seiring dengan terjadinya perubahan pada suatu hal, maka hal lain pun juga ikut berubah. Nitta (2011:183) menyatakan totomoni juga digunakan untuk menunjukkan adanya perubahan yang terjadi seiring dengan perubahan lainnya. Menurut Ichikawa (2015:427) to tomoni digunakan untuk menyatakan suatu 
perubahan yang sesuai dengan perubahan yang lainnya. Sejalan dengan itu Sunagawa (2002:348) juga menyatakan bahwa totomoni dapat digunakan untuk menyatakan perubaham. Secara struktur to tomoni dengan makna 'seiring dengan' dapat melekat pada verba, adjektiva, dan nomina. Berikut adalah contoh kalimat totomoni yang meyatakan 'seiring dengan':

$$
\begin{aligned}
& \text { 情熱は年齢とともに弱くなるが、 } \\
& \text { 習慣は年齢とともに強くなる。 } \\
& \text { Jounetsu / wa/ nenrei } \\
& \text { (ejje.weblio.jp) } \\
& \text { Gairah / } \underline{\text { PAR / usia }} \\
& \text { /to tomoni/ yowaku naru } \\
& \text { / seiring dengan / melemah } \\
& \text { /ga/shuukan / wa } \\
& \text { / PAR / kebiasaan / PAR } \\
& \text { /nenrei } \text { to tomoni } \\
& \text { / usia / seiring dengan } \\
& \text { I tsuyoku naru. } \\
& \text { / menguat. }
\end{aligned}
$$

'Meskipun seiring dengan bertambahnya usia gairah semakin melemah, akan tetapi kebiasaan menjadi menguat seiring dengan bertambahnya usia'

Pada kalimat (5) terdapat dua to tomoni dalam satu kalimat. Kedua to tomoni pada kalimat (5) sama-sama melekat pada nomina nenrei yang berarti 'usia'. Totomoni pada kalimat (5) digunakan untuk menjelaskan bahwa seiring dengan terjadinya perubahan suatu hal, maka hal yang lainnya pun juga ikut berubah. Pada klausa pertama kalimat (5) to tomoni menunjukkan bahwa seiring dengan bertambahnya usia maka perubahan yang terjadi adalah gairah atau tekad dari subjek semakin melemah. Selanjutnya pada klausa kedua to tomoni menunjukkan bahwa seiring dengan bertambahnya usia maka kebiasaan-kebiasaan dari subjek semakin menguat.

\section{Menyatakan 'Bersama Dengan'}

Selain digunakan untuk menyatakan 'pada saat yang sama' dan 'seiring dengan' to tomoni juga mengandung makna 'bersama dengan' digunakan untuk menunjukkan bahwa seseorang melakukan aktivitas tidak seorang diri, melainkan dilakukan bersama dengan orang lain.Ichikawa (2015:427) juga menyatakan bahwa to tomonidapat diartikan sebagai isshoni'bersama-sama'. Selaras dengan Ichikawa, Sunagawa (2002:348) menyatakan bahwa to tomoni digunakan untuk mewakili orang atau instansi dengan arti isshoniatau 'bersama'. Dari segi struktur to tomoni dengan makna 'bersama dengan' dapat melekat pada nomina.Berikut adalah contoh kalimat totomoni yang menyatakan 'bersama dengan':

$$
\begin{aligned}
& \text { この夏家族とともに仙台市に行 } \\
& \text { くつもりです。 (ejje.weblio.jp) } \\
& \text { Kono / natsu/ } \underline{\text { kazoku}} \\
& \text { Ini/ musim panas / } \underline{\text { keluarga }} \\
& \text { /to tomoni / Sendai-shi } \\
& \underline{\text { /bersama dengan / Sendai }} \\
& \text { / ni / iku / tsumori } \\
& \text { / PAR / pergi / bermaksud } \\
& \text { / desu. } \\
& \text { / KOP. }
\end{aligned}
$$$$
\text { (ejje.weblio.jp) }
$$

'Saya bermaksud pergi ke Sendai bersama dengan keluarga, pada musim panas kali ini'

Pada kalimat (6) to tomoni melekat pada pada nomina kazoku yang berarti 'keluarga'. To tomoni pada kallimat (6) digunakan untuk menjelaskan bahwa 
Kiryoku, Volume 3 No 42019

e-ISSN: 2581-0960 p-ISSN: 2599-0497

Tersedia online di http://ejournal.undip.ac.id/index.php/kiryoku

seseorang melakukan aktivitas tidak seorang diri, tetapi dilakukan bersama dengan orang lain. Pada kalimat (6) dijelaskan bahwa subjek bermaksud akan pergi ke Sendai pada musim panas kali ini, namun dalam kalimat disebutkan bahwa subjek tidak akan pergi sendirian, melainkan pergi bersama dengan keluarganya.

\section{Simpulan}

Berdasarkan pemaparan analisis data, dapat disimpulkan bahwa todoujini dan totomoni memiliki struktur dan makna sebagai berikut:

\section{ToDoujini}

a. Todoujini dengan makna 'pada saat yang sama', 'segera setelah', ataupun 'danjuga' dapat melekat pada verba, adjektiva, dan nomina.

b. Todoujini menyatakan berbagai makna, yaitu sebagai berikut;

(1) 'pada saat yang sama'

Makna ini digunakan untuk menunjukkan dua hal yang terjadi atau dilakukan pada waktu yang sama, baik berupa aktivitas, keadaan, ataupun peristiwa.Aktivitas-aktivitas yang terjadi pada todoujinidengan makna ini sebagian besar merupakan aktivitasaktivitas dengan jangka waktu pendek, atau tidak memerlukan waktu yang lama.

(2)'segera setelah'

Makna ini digunakan untuk menunjukkan bahwa suatu hal terjadi, segera setelah atau tidak lama setelah hal sebelumnya terjadi.

(3)'dan juga'

Makna ini digunakan untuk menunjukkan suatu hal atau seseorang memiliki peran yang mempunyai karakteristik lebih dari satu.

\section{ToTomoni}

a. Totomoni dengan makna 'pada saat yangsama' dapat melekat pada verba, adjektiva, dan nomina. Totomoni dengan makna 'seiring dengan' juga dapat melekat pada verba, adjektiva, dan nomina, namun untuk adjektiva $i$, adjektiva na jarang digunakan. Totomoni dengan makna 'bersama dengan' hanya dapat melekat pada nomina.

b. Totomoni menyatatakan berbagai makna, yaitu sebagai berikut:

(1) 'pada saat yang sama'

Makna ini digunakan untuk menunjukkan dua hal yang terjadi atau dilakukan pada waktu yang sama. To doujini dengan makna ini digunakan untuk menyatakan aktivitas-aktivitas yang dilakukan secara bersamaan. Aktivitas-aktivitas yang terjadi pada totomoni sebagian besar merupakan aktivitas-aktivitas yang memerlukan jangka waktu dalam pelaksanaannya.

(2) 'seiring dengan'

Makna ini digunakan untuk menunjukkan bahwa seiring dengan perubahan yang terjadi, maka hal lain pun juga kan ikut berubah.

(3) 'bersama dengan'

Makna ini digunakan untuk menunjukkan bahwa seseorang melakukan suatu hal atau aktivitas tidak seorang diri, melainkan bersama dengan orang lain.

\section{REFERENSI}

Fitriyani. 2012. Analisis Penggunaan Pola Kalimat To Tomoni, Ni Shitagatte, Ni Tomonatte dan Ni Tsurete dalam Kalimat Bahasa Jepang (Jurnal). Bandung: Universitas Komputer Indonesia 
Ichikawa, Yasuko. 2015. Chuukyuu Nihongo Bunpou to Oshiekata no Pointo. Tokyo: 3A Corporation.

Kholifah, Dwi Umi, 2017. Analisis Struktur dan Makna Adverbia Tomoni dalam Kalimat Bahasa Jepang (Skripsi). Semarang : Universitas Diponegoro.

Machida, Ken. 2015. Genggogaku Nyuumon. Tokyo: Kenkyusha.

Makino, Seichii, Michio Tsutsui. 2001. A Dictionary of Intermediate Japanese Grammar. Tokyo: The Japan Times, Ltd.

Nitta, Yoshio. 2011. Gendai Nihongo Bunpou 6. Tokyo: Kuroshio Shuppan.

Sudaryanto. 1993. Metode dan Aneka Teknik Analisis Bahasa. Yogyakarta: Duta Wacana University Press

Sunagawa, Yuriko dkk. 2002. Nihongo Bunkei Jiten. Tokyo: Kurisio Publishers.

SUMBER DATA

https://ejje.weblio.jp 